\title{
LEGAL EFFORTS OF TAX MANDATORY OBJECTIVES ON TAX PROVISIONS \\ (Study in the Regional Office of General Directorate of Taxation of South Jakarta I)
}

\author{
Andri Prasetyo Sumbaga ${ }^{1}$, Paisal Halim ${ }^{1}$, Syamsiah Badruddin ${ }^{1}$, \\ Saifullah Bombang ${ }^{2}$ dan Hardianto Djanggih ${ }^{3}$ \\ ${ }^{1}$ Institut Ilmu Sosial and Manajemen (STIAMI) Jakarta, Indonesia \\ ${ }^{2}$ Institut Agama Islam Negeri (IAIN) Palu, Indonesia \\ ${ }^{3}$ Fakultas Hukum,Universitas Tompotika Luwuk Banggai \\ Email: hardianto.djanggih@gmail.com
}

\begin{abstract}
The focus of this study is on the resolution of objections raised by Taxpayers in the Regional Office of DGT South Jakarta I. The theory used in this study refers to the opinion of Adam Smith in his book Wealth of Nations which states that a good tax collection must fulfill equity and equality requirements, certainty, convenience of payment, and efficiency. This study uses a naturalistic and interpretive qualitative approach that focuses on the process of resolving taxpayers' objections to a tax assessment as a legal effort. Data collection is done through interviews and direct observation on the object of research. The results of interviews and observations prove that the resolution of the objections to the South Jakarta I DGT Regional Office has been carried out in accordance with the provisions of the applicable tax regulations. This was also reinforced by statements made by Taxpayers who filed objections to the Regional Office of DGT South Jakarta I. The settlement of objections was also carried out to fulfill the rights and justice of the Taxpayers even though the decisions issued differed from the wishes of the Taxpayer. Settlement of objections seen from the rhythm of the work is considered effective, but when viewed from the time of completion, there are several applications that can be completed near the deadline. This is due to the large number of application files for reduction or elimination of administrative sanctions that enter, thus affecting the time to settle complaints.
\end{abstract}

Keywords: Objection Settlement, Tax, Determination Letter

\section{A. INTRODUCTION}

The 1945 Constitution of the Republic of Indonesia (1945 Constitution of the Republic of Indonesia 1945 Article 23A emphasized that tax and other levies are coercived for state needs are regulated by law (Achmad, Suranto\&Pujiyono, 2015:126). The imposition of taxes is basically a coercion of the state against economic units to reduce their income by paying taxes (Purnawan, 2011:36). This is

Yustisia Vol. 7 Number 3 (Sept.-Dec. 2018)

Legal Efforts Of Tax Mandatory ...

(C)2018; This is an Open Acces Research distributed under the term of the Creative Commons Attribution Licencee (https://Creativecommons.org/licences/by/4.0), which permits unrestricted use, distribution, and reproduction in any medium, provided the original works is properly cited. 
very basic because tax income has a very big role/influenceon state income (Nursadi, 2018:111).

The establishment of a tax law system is based on fairness (equity), eficiency, simplicity (Suhardi, 2016:32). As a matter of fact,in 1993 Law Number 6 is promulgated concerningGeneral Provisions and Taxation Procedures that regulated the existence of taxation system in Indonesia that embracedself assessment system, where the Taxpayers calculate, deposit, and report their own tax obligation without waiting for thetax assesment from the government. With theself assessment system, government expects honesty kejujuran and awareness from eachTaxpayer to carry out their tax obligations according to the applicable tax law. the trust given by the government according to the self assessment systemrequires Taxpayersto provide clear, correct and complete informations when filling out an Annual Notice Letter (SPT) according to the applicable tax law.

In practice, there are often differences in calculating between Dalam praktek seringkali terjadi perbedaan perhitungan antara tax apparatus and Taxpayerswhich is one reason for the emergence of tax disputes. Therefore, in the process through the tax audits often arise betweenTaxpayersandtax apparatus. This dispute can be caused by the differences in interpretation and understanding sof law provisons, differences in pointview inassesting of a fact, or could be due to disagreement in the process of verification.

Law dispute can also occur due to the differences in opinions betweentax apparatusandTaxpayersregarding the SKP issues. This dispute arises usually due to the tax determination conducted by Tax Service Officer where the Taxpayersare registered after going through the inspection process.

The implementation of inspection to test the taxpayers compliance or for other purposes, can be done through office check or field check (Pramono, 2016:8). If the Taxpayers feel that the tax assesment as the result of the inspection is not in accordance with the condition of the Taxpayers and argue that the amount of loss, amount of tax and deduction or tax collection are not as they should be, then Law Number 6 of 1993 Concerning the General Provision and Taxation Procedures provides space for the Taxpayers to submit the objection process to the tax assesment to the Directorate General of Taxes.

Objection is a legal means or channel that give the opportunity to the Taxpayers to seek for justice if Taxpayers feel that they are not treated according to the applicable provisions, or feel treated unfair by the tax apparatus through the publishing of tax assesment letter.

Objection by Taxpayers is used in order to create the a balance between the fulfillment of the obligations and the implementation of the Taxpayers rights in seeking justice as a motivation of their tax obligation fulfillment. However in reality,

508 Yustisia Vol. 7 Number 3 (Sept.-Dec. 2018) $\quad$ Legal Efforts Of Tax Mandatory ... 
the implementation of objection that carried out by the Directorate General of Taxes sometimes resolved for a long time and create dilemma between target achievement of tax income and the fulfillment of Taxpayers rights, while inevitable tax dispute always happen in the interaction between Taxpayers and Directorate General of Taxes in the task of securing state income in tax sector. Although tax is the main source of state income, but in the collection it should not be arbitary and sacfrifice the Taxpayers interest.

Research conducted by Pandiangan (2008:95) stated that the problem in the process of Taxpayers objection settlement is the presumption of Taxpayers that objection settlement which has been applied so far is less concerned the Taxpayers rights to get justice. This is because the existing services are still considered too bureaucratic, not transparent, too long, unclear even often felt convoluted. Likewise with the research of Rachmawati and Sariono (2011) which revealed that in calculating the tax amount, the difference in calculations between tax apparatus and taxpayers are often, this is one of the reason for the emergence of tax disputes. In terms of taxpayers submit the objection of Tax assesment letter and objection rejected, then taxpayers can submit an appeal.

Objection dispute resolved by the Regional Office of Wilayah DGT, if it has not recieved justice, then the next stage Taxpayers can submit an appeal to th Tax Court, which is the final decision.

As a new Regional Office of Directorate General of Taxes (DGT), which is the splitting of the Regional Office of the DGT in South Jakarta, Regional Office of DGT South Jakarta I which has been operating since October 5, 2015 become an interesting research object to do a research in order to find out whether the objection settlement that carry out by the Regional Office of DGT South Jakarta I has been in accordance with the applicable provision, whether it has has provided legal certainty and sense of justice for the Taxpayers, and how is the objection settlement effectiveness that is carried out by the Regional Office DGT of South Jakarta I.

\section{B. PROBLEM STATEMENT}

Based on the things mentioned above, the researcher intends to evaluate the process of resolving the legal efforts made by Taxpayers to obtain justice through submitting an objection process.

The questions in this research are:

1. Has the objection settlement process carried out by the Regional Office of DGT

South Jakarta I been in accordance with applicable regulations?

2. Does the objection settlement carried out by the Regional Office of DGT South

Jakarta I provide legal certainty and a sense of justice for Taxpayers? 
3. How is the effectiveness of the objection settlement conducted by the Regional Office of DGT DJP South Jakarta I?

\section{RESEARCH METHODS}

\section{Research Approach}

In the preparation of this study, the authors used qualitative methods. Qualitative research is a process (Sulaiman, 2018: 226) with a naturalistic and interpretive approach (which focuses on understanding phenomenas in the human social world and considering the focus of research on the process of Taxpayers objection settlement to the Tax Assessment Letter as a legal effort that has many in terms of and not monocausal, meaning that there is no single cause of a social reality.

\section{Determination of Data Collection}

According to Neuman (2006: 411), there are 4 (four) ideal types of an informant or the ideal field of information, namely:

The informant who is totally familiar with the culture The individual I currently involved in the field The person can spend time with the researcher Nonanalytic individuals make better informant

The ideal informant according to Neuman (2006: 412) is someone who has long been involved directly and has a lot of experiences related to research topics, so that it can provide information that is useful to researchers and the data obtained is valid and accountable.

As for the informants in this study are:

a. Head of Evaluation Section for Objection, Appeal and Reduction of Regional

Office of DGT South Jakarta I.

b. Objection Review Officer of Regional Office of DGT South Jakarta I.

c. 3 (three) Taxpayers at Regional Office of DGT South Jakarta I.

Informants in this study were parties related to the topic that became the background in this research.

\section{Data collection technique}

Referring to Patton (2002: 4), there are three techniques for collecting data in a qualitative approach, namely: 1) in-depth, opened ended interview, 2) direct observation and 3) written document. In the first technique, namely in-depth interviews, the author will try to capture the answers related to the research topic.

Guidelines and summary interviews are attached at the end of this research. In direct observation or direct observation technique, the writer has the opportunity

510 Yustisia Vol. 7 Number 3 (Sept.-Dec. 2018) Legal Efforts Of Tax Mandatory ... 
to observe the objection process submitted directly by the Taxpayers and objection settlement carried out by the Regional Office of DGT South Jakarta I. In the written document technique, the author will discuss the results of the research.

\section{Data Analysis}

This research uses analysis carried out by understanding and compiling data that has been systematically obtained so that an overview of the problem or the conditions to be studied is obtained. After analyzing the data, conclusions will be drawn using deductive thinking methods, namely a pattern of thinking that is based on things that are general in nature, then a generalization or conclusions are drawn specifically (Sukanto, 2004: 50).

\section{Data Validity Test}

According to Moleong as quoted by Ibrahim (2015: 120-121), there are four data validity criteria in a study, namely credibility, transferability, dependability, confirmability.

\section{Research Location}

This research is conducted at the Regional Office of DGT South Jakarta I, specifically in the areas of Objection, Appeal and Reduction.

\section{Framework}

Tax collection practices should provide legal guarantees and justice to citizens as taxpayers and to the state as tax collectors (Hardiyantina, 2018: 86). In the practice of Tax collection, there are often differences in calculations between tax apparatus and Taxpayers, which is one of the reasons for tax disputes. This dispute can be caused by differences in interpretation and understanding of tax provisions, differences in viewpoints in assessing a fact, or it can also be due to disagreement in the process of proof.

Tax disputes can also occur due to differences of opinion between the tax apparatus and Taxpayers regarding the Tax Assessment Letter issued (Ismail, 2010: 271). This dispute arises usually because of the tax determination made by the Tax Service Office where the Taxpayers are registered, after going through the inspection process.

If Taxpayers feel that the determination of the examination are not in accordance with the conditions of Taxpayers and argue that the amount of loss, amount of tax and deduction or tax collection is not as it should be, then the KUP law provides Taxpayers room to submit the objection process to the Directorate General of Taxes through the Office Tax Services where Taxpayers are registered. 
Objection is the legal effort of Taxpayers to obtain justice aimed at resolving disputes related to the issuance of a Tax Assessment Letter. In this objection, the Taxpayers provide the arguments underlying the tax calculation, which will then be examined by the Research Team. Objection whether the calculations and arguments of Taxpayers fulfill the applicable taxation provisions or not.

In implementing objections, Taxpayers have rights and obligations that must be fulfilled, as well as the Objection Research Team which has the authority and obligations that must be fulfilled. Therefore, objection settlement must be carried out fairly with procedures and processes that are fast, simple and inexpensive, but still based on applicable tax provisions so that it can provide legal certainty.

\section{E. DISCUSSION AND RESEARCH RESULT}

\section{Overview Of Research Objects}

The Regional Office of DGT South Jakarta I which is the object of research is the expansion of the Regional Office DGT South Jakarta I. The Regional Office of DGT South Jakarta I Is officially began operations on October 5, 2015, with work areas covering a portion of the city of South Jakarta consisting of Setiabudi Subdistrict, Mampang Prapatan Subdistrict, Tebet Subdistrict, and Pancoran Subdistrict.

Regional Office of DGT South Jakarta I oversees 8 (eight) Tax Service Offices (KPP), namely Tax Office of South Jakarta City I, Jakarta Setiabudi Satu KPP Pratama, Jakarta Setiabudi Dua KPP Pratama, Jakarta Setiabudi Tiga KPP Pratama, Jakarta Setiabudi Empat KPP Pratama, Jakarta KPP Pratama Mampang Prapatan, Jakarta Tebet KPP Pratama, and Jakarta Pancoran KPP Pratama.

The number of employees of the Regional Office of DGT South Jakarta I at the time of the research was 117 people which can be seen in the following table:

Tabel 1. The Number of Employees of the Regional Office of DGT South Jakarta

\begin{tabular}{|l|c|}
\hline \multicolumn{1}{|c|}{ Position/Class } & Total \\
\hline Eselon II & 1 \\
\hline Eselon III & 6 \\
\hline Eselon IV & 21 \\
\hline Fungsional & 22 \\
\hline Objection Reviewer & 24 \\
\hline Treasurer & 1 \\
\hline Operator Console & 2 \\
\hline Executor & 67 \\
\hline
\end{tabular}

Source: Profile Book of the Regional Office of DGT South Jakarta I, 2016

512 Yustisia Vol. 7 Number 3 (Sept.-Dec. 2018) $\quad$ Legal Efforts Of Tax Mandatory ... 


\section{Data Validity Test Results}

a. Credibility

As the character of qualitative research, researchers are research instruments and the main tools in research. Therefore the participation of researchers is crucial in the research process. Regarding this, the credibility of the data is reliable because the researcher is an employee at the Regional Office of DGT South Jakarta I.

b. Transferability

Transferability in the qualitative depends very much on the knowledge of a researcher (in the context of the sender) with the reader (in the context of the recipient). The researcher is assigned in the objection field so that the data obtained can be transferred to the recipient such as the Directorate General of Taxes and Taxpayers related to taxation issues.

Data, data sources, including informants in this research are interrelated. The linkage is data and data sources in this research related to taxation issues, especially regarding objections.

c. Confirmability

The datas obtained in this research were obtained from the parties related to the objections, namely the Regional Objection, Appeal and Reduction field of the Regional Office of DGT South Jakarta I, and Taxpayers who submit objections so that data certainty was reliable.

\section{Data Analysis Strategy}

Primary data is obtained from the results of interviews directly with informants in this study, while secondary data is obtained from officers who handle objections reporting administration. Data is trusted because it is obtained from parties that are directly related to the topic of research, in this case, who know and understand about the process of submitting and objection settlement of tax. The purpose of the interview with the Regional Office of DGT South Jakarta and Taxpayers is for the researchers to get a balance of data or information so that the results of this study would be balanced.

The results of interviews with informants and secondary data, the author writes on the results of the research without reducing or adding the information provided. This information is reliable because it is obtained from parties which have competence in their duties, jobs and fields. 


\section{DISCUSSION AND RESEARCH RESULT}

a. The Fulfillment of the Objection Settlement Process in the Regional Office of DGT South Jakarta I of the applicable provisions

From the observations and interviews with the Head of Evaluation Section Objection, Appeal and Reduction, Regional Objection Reviewers of the Regional Office of DGT South Jakarta I and Taxpayers who submitted objections as informants in this research, it can be concluded that the procedures and procedures for each stage of objection settlement carried out by the Regional Office of DGT South Jakarta I Is in accordance with applicable provisions. This process is the fullfilment of process and procedure, starting from receiving files, calling Taxpayers and parties related to file objection requests, discussing tax disputes to sending Decision of Objection.

\section{b. Objection settlement to Provide Legal Certainty and a Sense of Justice for Taxpayers}

The objection settlement process carried out by the Regional Office of DGT South Jakarta I is always sought to fulfill a sense of justice for Taxpayers, because it is carried out based on the predetermined procedures and is treated equally to every Taxpayers who submit an objection request.

From the results of interviews with the Taxpayers who submit objections as informants in this research, information was obtained that the submittin of an objection was an attempt to obtain legal certainty over the issued Tax Assessment Letter.

But from the explanation of the Head of Evaluation Section of Objection, Appeal and Reduction, based on the KUP Law, objections are not the only legal effort for Taxpayers to obtain justice against the Tax Assessment

Letter issued by the Directorate General of Taxes based on the results of the examination. In addition to raising objections, Taxpayers can submit a reduction application or the elimination of administrative sanctions for a Tax Assessment Letter or a request for reduction or cancellation of a Incorrect Tax Assessment Letter, which is submitted to the Directorate General of Taxes under Article 36 of the KUP Law. This stage is an attempt made by Taxpayers to make corrections to the provisions issued by the tax apparatus.

In the principle, the objection settlement process carried out by the Regional Office of DGT South Jakarta I is always sought to provide legal certainty to Taxpayers, because it is carried out basesd on the predetermined procedures and is treated equally to each Taxpayers who submit an objection

514 Yustisia Vol. 7 Number 3 (Sept.-Dec. 2018) $\quad$ Legal Efforts Of Tax Mandatory ... 
request, even though the objection decision is received by Taxpayers can be different.

Objection settlement in the Regional Office of DGT South Jakarta I also based on fulfilling the rights and justice for Taxpayers. But often Taxpayers feel a lack of sense of justice because the objections are still being carried out by the DGT so that the decision can still be in favor of the results of the tax audit that is done by the tax apparatus. Regarding the fulfillment of Taxpayers' rights in order to prove the reason for their objections, according to the Researcher, Taxpayers have been given sufficient time to reflect the fulfillment of Taxpayers' rights. Taxpayers can provide data that supports their objections as long as the objection decision has not been issued.

\section{c. Effectiveness of Objection Settlement in the Regional Office of DGT South Jakarta I}

The objection service is one of many public services. according to Sondang Siagian (1996: 60), there are several criteria that can be used to measure the work effectiveness of organizations that provide services, including time factors, precision factors, and service delivery style factors (Moonti, et.al, 2018:155).

If viewed from the time factor, the objection settlement by the Regional Office of DGT South Jakarta I was not effective because the previous objection settlement process that could be completed within 9 months must now be completed within 10 months.

When viewed from the carefulness factor, objection settlement by the South Jakarta Regional Office of DJP I has been effective because the objection settlement process and procedures have been carried out based on the applicable provisions, the process of objection settlement through step by step which makes the settlement more targeted and effective, and the request for documents to Taxpayers that is needed to prove the objection based on the time limit specified and the requested documents are only limited to those relating to the objection so that Taxpayers can focus on proving the corrected posts by the Examiner are wrong.

Whereas when viewed from the style factor of service delivery, objection settlement carried out by the Regional Office of DGT South Jakarta I has been effective because in addition to resolving objections, Objection Reviewers must also resolve the number of reduction requests or eliminate administrative sanctions, resolve objections and reduce or eliminate administrative sanctions from Taxpayers which actually have moved to the Regional Office of DGT South Jakarta II, and sometimes Objection Reviewers must confront uncooperative Taxpayers in providing data regarding objections submitted. 
From the results of interviews with the Head of Evaluation Section Objection, Appeal and Reduction of Regional Office of DGT South Jakarta I, an explanation is obtained that the objection settlement carried out by the Regional Office of DGT South Jakarta I is effective if it is viewed from the rhythm of the work and done by the procedures and procedures that have been set. However, if it is associated with the time period for completion, it is not yet effective, this is because the number of file requests for reduction or elimination of administrative sanctions that are entered and must be completed, so that the objection settlements are slightly longer than the usual time.

From the results of interviews and observations of researchers, it can be seen that the objection settlement in the Regional Office of DGT South Jakarta I has been carried out based on the taxation law related to the applicable objection settlement. Objection settlement in the Regional Office of DGT South Jakarta I is also carried out while paying attention to the fulfillment of Taxpayers' rights who feel disadvantaged over the Tax Assessment Letter issued by the tax apparatus so that it has provided a sense of justice and legal certainty to Taxpayers.

\section{E. CLOSING}

\section{Conclusion}

From the results of research and discussion, conclusions can be taken as follows:

a. The objection settlement process in the Regional Office of DGT South Jakarta I has been carried out based on the applicable taxation provisions.

b. Objection settlement carried out by the Regional Office of DGT South Jakarta I has been done to fulfill the rights and justice, as well as legal certainty for Taxpayers even though there are decisions issued that are different from the expectation of the Taxpayers.

c. Objection settlement seen from the rhythm of the work is considered to be effective, but when viewed from the time of completion, there are several applications that can only be completed beyond the time usually carried out by the Regional Office of DGT South Jakarta I.

\section{Suggestion}

From the results of the research and the conclusions above, researchers can give advice so that it can be a consideration for the Regional Office of DGT South Jakarta I as follows:

516 Yustisia Vol. 7 Number 3 (Sept.-Dec. 2018) $\quad$ Legal Efforts Of Tax Mandatory ... 
a. Processing objection settlement more quickly so that Taxpayers will immediately get certainty and also be balanced with a fair decision for Taxpayers so that Taxpayers get satisfaction during the objection resolution process.

b. Re-implement Superior Tax Services so that the entire objection settlement process can be completed at the specified time.

c. The level of resolution of the objection file, both the quality and the speed of completion, should be improved in order to provide better service.

d. Divide the time between the work on the objection file and the application for reduction or the elimination of administrative sanctions in a certain schedule so that the completion of both applications can be effective.

e. The Head of the Objection, Appeal and Reduction Division in order to give a fair workload to each Observer so that there is no objection Reviewer having a workload that is less than the other Objection Reviewers.

\section{BIBLIOGRAPHY:}

\section{Books:}

Ibrahim, 2015, Qualitative Research Methodology, Alfabeta: Bandung.

Neuman, W. Lawrence, 2006, Social Research Methods: Qualitative and Approach, Pearson

Pandiangan, Liberti, 2008, Modernisation and Reformation of Taxation Services Based on the Latest Law, PT Elex Media Komputindo: Jakarta.

Patton, Michael, 2002, Qualitative Evaluation Method, SAGE Publications Inc: California.

Siagian, Sondang P, 1996, Human Resources Management, Bumi Aksara: Jakarta

Sukanto, Soerjono, 2004, Law Research Introduction, Rajawali Pers: Jakarta.

\section{Journals:}

Achmad, Suranto, Pujiyono, "Harmonisation of Regional Law Regulation In Fiscal Desentralisation and Regional Autonomy Framework (Sukoharjo District, Surakarta City, and Karanganyar District Study)", Yustisia Law Journal, Vol. 4, No. 2, 2015.

Hadiyantina, Shinta, "Conceptualization of Law Forgivness in the Context of Tax Law Reformation in Indonesia", Law Arena Journal, Vol. 11, No. 1, 2018. 
Ismail, Tjip, "Tax Justice and Legal Certainty in the Midst of Economic Globalization", Ius Quia Iustum Journal, Vol. 17, No. 2, 2010.

Moonti, Roy Marthen, et.al. "Assessment of Work Performance of State Civil Apparatuses (ASN) in the Agriculture Agency of the Province of Gorontalo", Jurnal Ilmiah Kebijakan Hukum, Vol.12, No.2, 2018.

Pramono, Widyo, "Equalization of Perception and Cooperation in Inspection in the Taxation Field to Support the Optimalization of State Income", Yustisia Law Journal, Vol. 5, No. 1, 2016.

Purnawan, Amin, "Reconstruction of Income Tax Collection System (Pph) Justice Value Based Agency", Journal of Legal Dynamic, Vol. 11, Edisi Khusus, 2011.

Nursadi, Harsanto, "Administrative Legal Action (State) Taxation that can Cause Criminal Actions", Law Journal \& Development, Vol. 48, No. 1, 2018.

Rachmawati, Agung and Sariono, Joko. 2011. "Legal Effort of Taxpayers to Underpayment Tax assesment Letter determined by Tax apparatus in the Fulfillment of Taxpayers Rights".Perspektif, Volume 14, No. 4, 2011.

Suhardi, "Unification of Formal Tax Law in Nasional Tax Law System", Yuridika, Vol. 31, No. 1, 2016.

Sulaiman, "Legal Research Paradigm”, Kanun Journal of Law Science, Vol. 20, No. 2,2018 .

518 Yustisia Vol. 7 Number 3 (Sept.-Dec. 2018) $\quad$ Legal Efforts Of Tax Mandatory ... 